\title{
Synapsin I in PC12 Cells. Il. Evidence for Regulation by NGF of Phosphorylation at a Novel Site
}

\author{
Carmelo Romano, Robert A. Nichols, and Paul Greengard \\ Laboratory of Molecular and Cellular Neuroscience, Rockefeller University, New York, New York 10021
}

\begin{abstract}
NGF treatment of PC12 cells caused a rapid increase in the state of phosphorylation of synapsin I. This phosphorylation of synapsin $I$ is accompanied by a decrease in its electrophoretic mobility on SDS-PAGE. Phosphopeptide fingerprint analysis of the synapsin I revealed that this phosphorylation occurred on a particular phosphopeptide, designated peptide N. Phosphoserine was the only phosphoamino acid detected in peptide N. Partially purified PC12 synapsin I was a substrate for several protein kinases known to be capable of phosphorylating brain synapsin I, but none of these kinases phosphorylated synapsin I on peptide $\mathbf{N}$. The results suggest that the NGF-stimulated phosphorylation of synapsin I may be mediated by a novel protein kinase.
\end{abstract}

NGF is a peptide hormone necessary for the normal development and maintenance of sympathetic and certain sensory neurons (Levi-Montalcini and Angeletti, 1968; Greene and Shooter, 1980; Thoenen and Barde, 1980; Bradshaw, 1983). The mechanism of action of NGF is unknown. Studies of neurons and neuron-like cells in culture demonstrate that certain biochemical and morphological actions of NGF occur very rapidly (within seconds or minutes) (Horii and Varon, 1977; Connolly ct al., 1979; McGuire and Greene, 1979; Halegoua and Patrick, 1980; Seeley and Greengard, 1983; Greene et al., 1984; Curran and Morgan, 1985; Greenberg et al., 1985; Landreth and Reiser, 1985). We demonstrate here that synapsin I, a neuron-specific phosphoprotein present in PC12 cells, undergoes a rapid modification in electrophoretic mobility upon treating intact cells with NGF. A different modification in electrophoretic mobility occurs rapidly upon treating intact cells with dibutyryl cyclic AMP (dbcAMP). The NGF-stimulated modification is accompanied by phosphorylation of the protein. We further demonstrate that the kinase responsible for this phosphorylation has a substrate specificity different from that of several known synapsin I kinases.

\section{Materials and Methods}

Partial purification of PC12 synapsin I. A cell extract enriched in synapsin I was prepared from PC12 cells by a modification of the method of Ueda and Greengard (1977). All steps were performed at $0-4^{\circ} \mathrm{C}$. Nine grams (wet weight) of PC12 cells were homogenized in $50 \mathrm{ml}$ of $10 \mathrm{~mm}$ phosphoric acid $/ 5 \mathrm{~mm} \beta$-mercaptoethanol $(\beta \mathrm{ME}) / 1$ mM EDTA using a Teflon-glass homogenizer. The $\mathrm{pH}$ was adjusted to 2.5 with $\mathrm{HCl}$, and

Received Jan. 31, 1986; revised Oct. 28, 1986; accepted Dec. 15, 1986.

This work was supported in part by grants (MH-39327 and NS-21550) to P.G. C.R. was a NIH postdoctoral fellow (NS06778). R.A.N. was a Muscular Dystrophy Association postdoctoral fellow.

Correspondence should be addressed to Dr. Carmelo Romano, Department of Pharmacology, University of Pennsylvania, 36th Street and Hamilton Walk, Philadelphia, PA 19104.

Copyright (C) 1987 Society for Neuroscience $0270-6474 / 87 / 051300-07 \$ 02.00 / 0$ the acid-insoluble material was pelleted by centrifugation at $15,000 \times$ $g$ for $30 \mathrm{~min}$. The pH of the supernatant was adjusted to 8.1 with $\mathrm{NaOH}$. The protease inhibitors leupeptin and PMSF were added to final concentrations of $20 \mu \mathrm{g} / \mathrm{ml}$ and $50 \mu \mathrm{M}$, respectively. CM-cellulose (Whatman CM-52), $10 \mathrm{gm}$, that had been equilibrated with Tris buffer $(10 \mathrm{~mm}$ Tris, pH 8.0, containing $5 \mathrm{~mm} \beta \mathrm{ME}, 1 \mathrm{mM}$ EDTA, $20 \mu \mathrm{g} / \mathrm{ml}$ leupeptin, $50 \mu \mathrm{M}$ PMSF) was added to the extract, and batch adsorption was carried out for $1 \mathrm{hr}$ with gentle shaking. After centrifugation, the supernatant was removed and the resin was subjected to batch elution using Tris buffer containing $0.4 \mathrm{M}$ ammonium chloride for $1 \mathrm{hr}$ with gentle shaking. The eluate was separated from the resin by centrifugation, and solid ammonium sulfate was added to $50 \%$ saturation. The precipitate was redissolved in a minimal volume of Tris buffer and dialyzed against several changes in the same buffer. This material was dialyzed against $50 \%(\mathrm{vol} / \mathrm{vol})$ glycerol/Tris buffer and stored at $-20^{\circ} \mathrm{C}$.

Phosphorylation of synapsin I with purified kinase. Purified rat brain synapsin I, $2 \mu \mathrm{g}$ (kindly provided by Dr. Werner Schiebler), or partially purified PC1 2 synapsin I ( $40 \mu \mathrm{l}$ of the preparation described above) was phosphorylated in a reaction mixture containing Tris- $\mathrm{HCl}, 50 \mathrm{~mm}, \mathrm{pH}$ $7.5 ; \mathrm{MgCl}_{2}, 4.0 \mathrm{~mm}$; EGTA, $0.25 \mathrm{~mm}$; dithioerythritol, $2.0 \mathrm{~mm} ; \gamma_{-}{ }^{32} \mathrm{P}-$ ATP (New England Nuclear, $2000 \mathrm{Ci} / \mathrm{mmol}$ ), $50 \mathrm{~nm}$; and protein kinase as indicated. Catalytic subunit of cyclic AMP-dependent protein kinase was used at a final concentration of $9 \mu \mathrm{g} / \mathrm{ml}$. Reactions using calcium/ calmodulin-dependent protein kinase I (final concentration, $5 \mu \mathrm{g} / \mathrm{ml}$ ) or calcium/calmodulin-dependent protein kinase II (final concentration, $20 \mu \mathrm{g} / \mathrm{ml}$ ) contained $0.5 \mathrm{mM} \mathrm{CaCl}_{2}$ and $30 \mu \mathrm{g} / \mathrm{ml}$ calmodulin. Reactions using protein kinase $\mathrm{C}$ (final concentration, $0.4 \mu \mathrm{g} / \mathrm{ml}$ ) contained 0.5 $\mathrm{mM} \mathrm{CaCl}_{2}, 25 \mu \mathrm{g} / \mathrm{ml}$ phosphatidylserine, and $0.1 \mu \mathrm{g} / \mathrm{ml}$ diolein. Catalytic subunit of cyclic AMP-dependent protein kinase and calcium/calmodulin-dependent protein kinase I were kindly provided by Dr. Angus C. Nairn. Calcium/calmodulin-dependent protein kinase II was kindly provided by $\mathrm{Dr}$. Teresa McGuinness. Protein kinase $\mathrm{C}$ was kindly provided by Dr. Katherine Albert. The reaction was initiated by the addition of $\gamma^{-32} \mathrm{P}$-ATP, carried out for $10 \mathrm{~min}$ at $30^{\circ} \mathrm{C}$, and stopped by the addition of SDS (final concentration, 1\%). Purification of the phosphorylated synapsin I from the reaction mixture was acheived by immunoprecipitation followed by SDS-PAGE, as described in the accompanying paper (Romano et al., 1987).

Peptide mapping. Phosphopeptide fingerprint analysis after complete digestion with trypsin and chymotrypsin was performed as described by Huttner et al. (1981), except that both enzymes were present at 100 $\mu \mathrm{g} / \mathrm{ml}$.

Phosphoamino acid analysis of peptide $N$. Using the autoradiogram as a guide, peptide $\mathrm{N}$ was scraped off the phosphopeptide fingerprint thin-layer plate and eluted into $1 \mathrm{ml}$ of $1 \mathrm{~N} \mathrm{HCl}$. After lyophilization, the phosphopeptide was resuspended in $6 \mathrm{~N} \mathrm{HCl}$ and hydrolyzed under vacuum for $1.5 \mathrm{hr}$ at $105^{\circ} \mathrm{C}$ (Bylund and Huang, 1976). The hydrolyzed phosphopeptide was then dried and resuspended in formic acid/acetic acid $/ \mathrm{H}_{2} \mathrm{O}, 1: 10: 89$ ( $\left.\mathrm{vol} / \mathrm{vol} / \mathrm{vol}\right), \mathrm{pH} 1.9$, and phosphotyrosine, phosphoserine, and phosphothreonine standards were added. This mixture was spotted onto cellulose thin-layer plates and subjected to 2-dimensional electrophoresis as described by Hunter and Sefton (1980).

Other methods. Other methods used in these studies were described in the accompanying paper (Romano et al., 1987).

\section{Results}

When PC1 2 cells were treated with NGF for $1 \mathrm{hr}$, the electrophoretic mobility of synapsin I in SDS-PAGE decreased. As the 


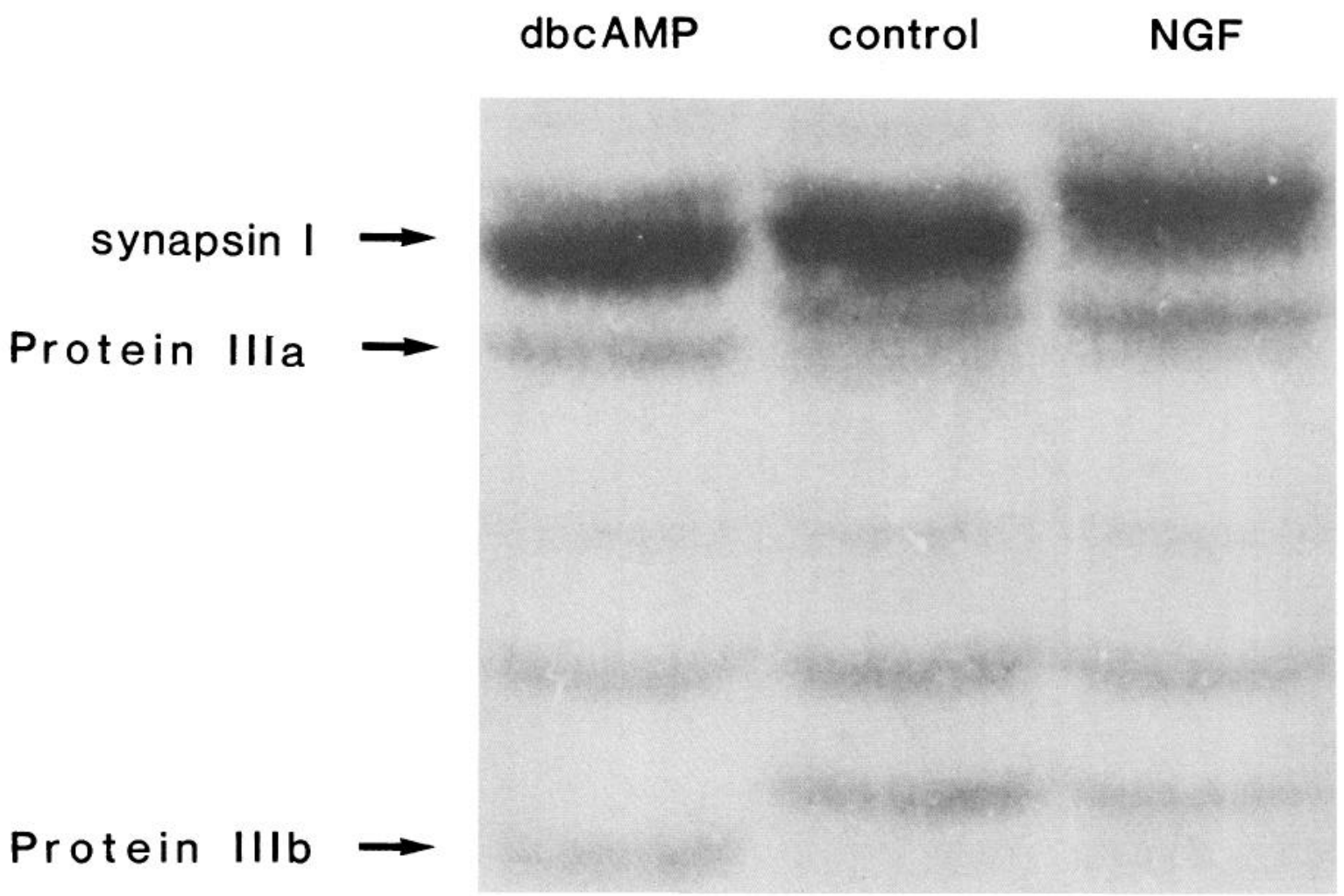

Figure 1. Effects of NGF and dbcAMP on the electrophoretic mobility of synapsin I and related proteins in PC12 cells. PC12 cells were treated with NGF $(0.25 \mu \mathrm{g} / \mathrm{ml})$ or dbcAMP $(1.0 \mathrm{~mm})$ for $1 \mathrm{hr}$ and solubilized in $1 \%$ SDS. Proteins in the homogenate were separated by SDS-PAGE, transferred electrophoretically to nitrocellulose, and immunolabeled using an antibody that cross-reacts with synapsin I and proteins IIIa and IIIb. The region of the gel transfer containing synapsin I and protein III is shown.

immunolabeled gel transfer in Figure 1 demonstrates, neither the immunologically related proteins IIIa and IIIb nor the several visible background bands underwent such a change. When cells were treated with dbcAMP for $1 \mathrm{hr}$, the electrophoretic mobility of synapsin I and proteins IIIa and IIIb, but not that of the background bands, increased (Fig. 1). Another analytical method-immunoprecipitation of synapsin I and proteins IIIa and IIIb from solubilized extracts of PC12 cells labeled biosynthetically with ${ }^{35} \mathrm{~S}$-methionine and treated with NGF or dbcAMP-revealed identical mobility alterations (see Fig. 4 for the data concerning synapsin I). None of the major cellular proteins underwent a change in electrophoretic mobility upon treatment of the cells with NGF or dbcAMP, as shown by SDSPAGE followed by Coomassie blue staining (data not shown).

The NGF effect was rapid and transient (Fig. 2). The mobility shift was visible within 15 min following addition of NGF to the culture medium. After $6 \mathrm{hr}$ in the continued presence of NGF, the original electrophoretic mobility was partially restored.

Precise quantitation of the extent of the shift seen in response to NGF was difficult owing to the relatively small change in electrophoretic mobility. Nevertheless, it was clear qualitatively that concentrations of $7 \mathrm{~S} \mathrm{NGF}$ less than $3 \mathrm{ng} / \mathrm{ml}$ were ineffective and those greater than $10 \mathrm{ng} / \mathrm{ml}$ were maximal (Fig. 3).

Pulse-chase experiments showed that the modifications induced by NGF and dbcAMP were posttranslational, not cotranslational. A $1 \mathrm{hr}$ labeling period with ${ }^{35} \mathrm{~S}$-methionine was followed by a $24 \mathrm{hr}$ chase period in complete medium. At the end of this chase period, treatment with NGF or dbcAMP induced their characteristic effects on synapsin I and proteins IIIa

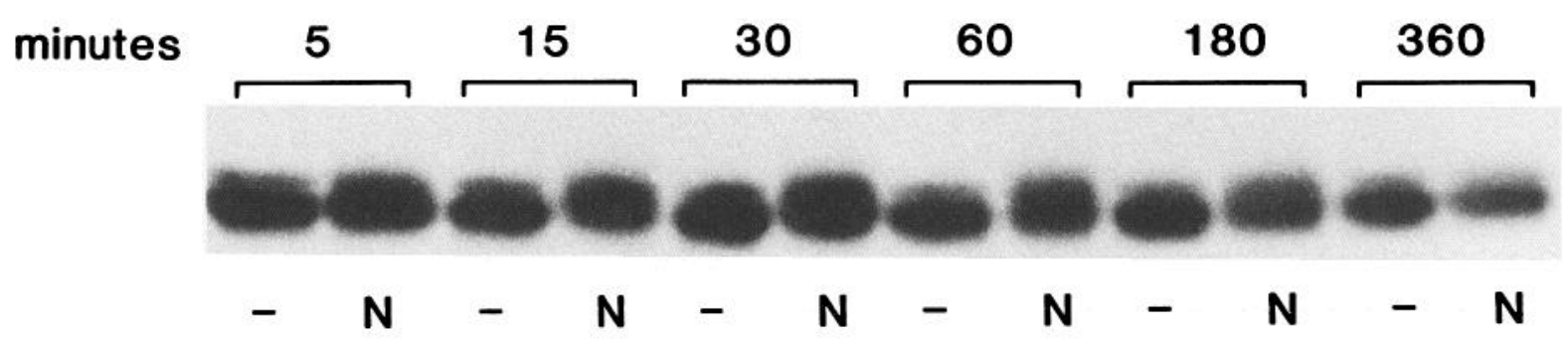

Figure 2. Time course of the NGF-induced shift in the electrophoretic mobility of synapsin I. PC12 cells were labeled by incubation with ${ }^{35} \mathrm{~S}$ methionine for $1 \mathrm{hr}$. After removal of the labeling medium and washing, the cells were further incubated for the indicated times in the absence $(-)$ or presence $(N)$ of NGF. Cells were solubilized in 1\% SDS and the synapsin I purified by immunoprecipitation followed by SDS-PAGE and visualized by fluorography. 


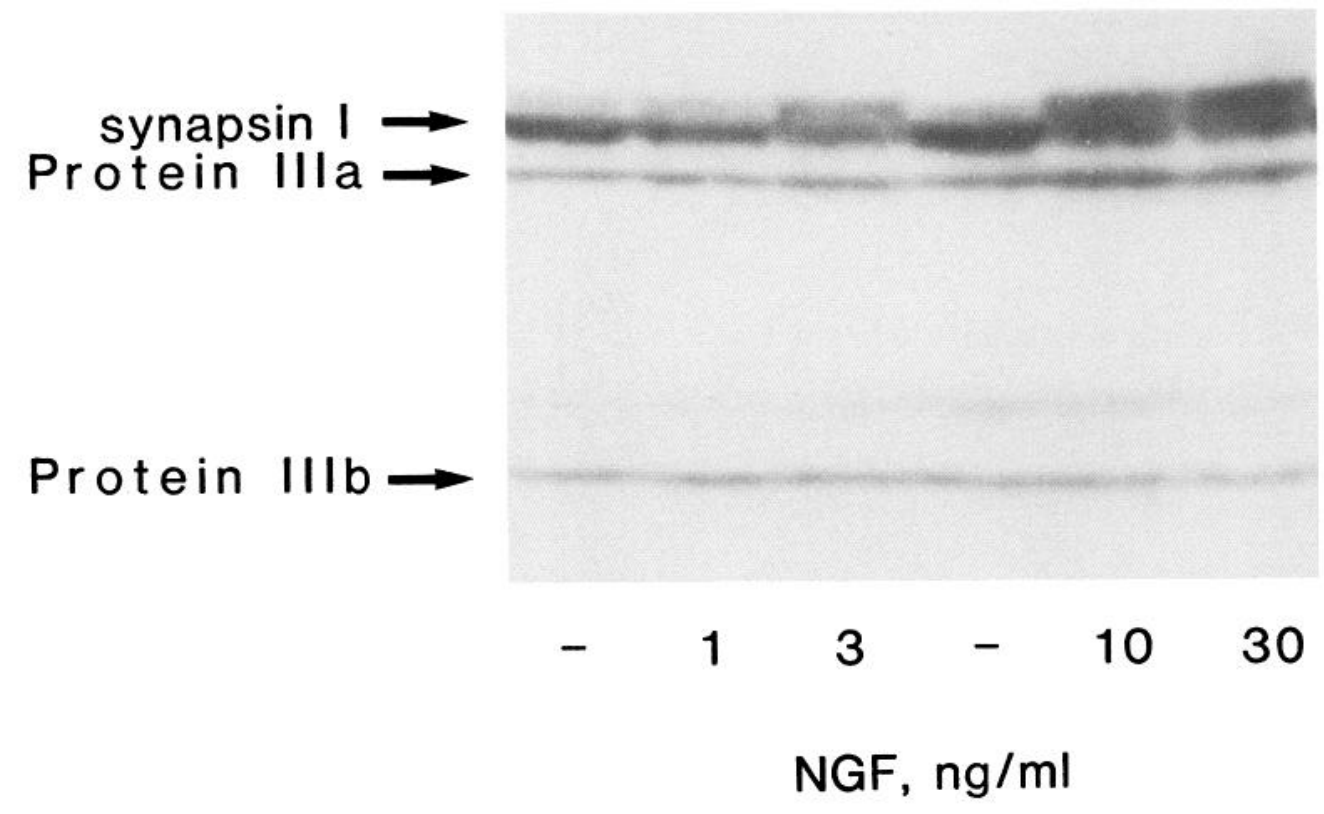

Figure 3. Dose-response relationship of the NGF-induced shift in the electrophoretic mobility of synapsin I. PC12 cells were incubated for $1 \mathrm{hr}$ in the absence $(-)$ or presence of the indicated concentrations of NGF. The cells were solubilized and the synapsin I analyzed by immunolabeling of a gel transfer. Note the lack of effect of NGF on the electrophoretic mobility of any protein except synapsin $\mathrm{I}$. The region of the gel transfer containing synapsin I and protein III is shown.

and IIIb in these pulse-labeled cells, as shown for synapsin I in Figure 4.

Several other experiments were carried out to characterize further the effects of NGF and dbcAMP on the electrophoretic

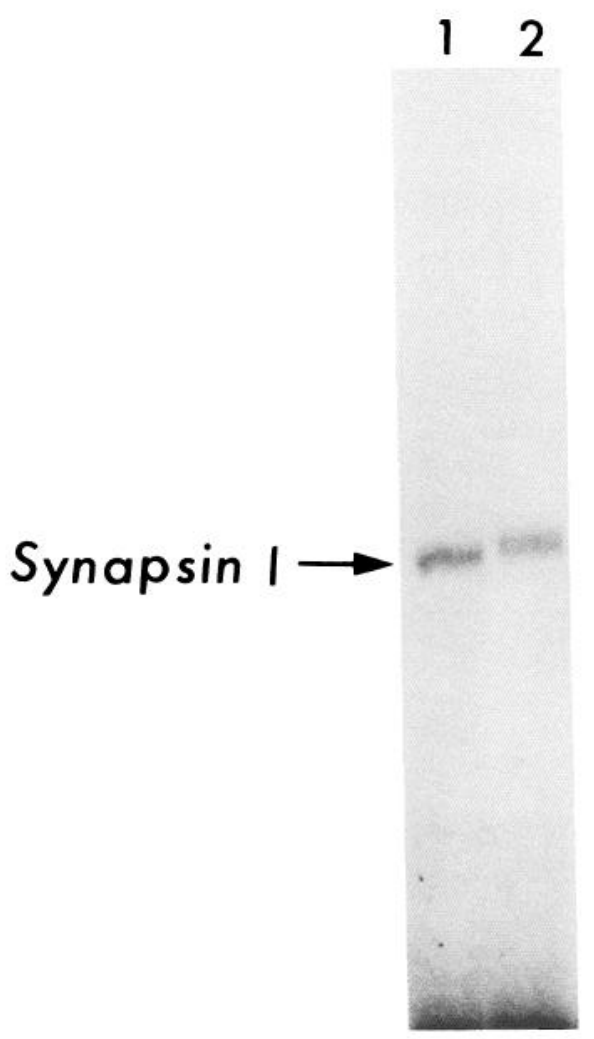

Figure 4. Effect of NGF on pulse-chase-labeled synapsin I. PC1 2 cell proteins were labeled by incubation with ${ }^{35} \mathrm{~S}$-methionine for $1 \mathrm{hr}$. After removal of the labeling medium and washing, the cells were incubated in complete medium overnight. Following this chase period, NGF (lane 2) was added to the prelabeled cultures and the incubation continued for $1 \mathrm{hr}$. A control culture (lane 1) was incubated for the same total time as the treated cultures. Synapsin I was purified by immunoprecipitation followed by SDS-PAGE and visualized by fluorography. mobility of synapsin I and proteins IIIa and IIIb. The NGF effect on the electrophoretic mobility of synapsin I occurred in washed cells suspended in a simple buffered salt solution, indicating that neither attachment of cells to substrate nor specialized serum or medium factors were required. Forskolin (10 $\mu \mathrm{M}, 20 \mathrm{~min}$ ), a diterpene alkaloid that activates adenylate cyclase (Seamon et al., 1981), including the adenylate cyclase of PC12 cells (Rabe et al., 1982), induced the same mobility alterations in synapsin I and proteins IIIa and IIIb as did dbcAMP. Neither the effect of NGF nor that of dbcAMP required the presence of extracellular $\mathrm{Ca}^{2+}$. Both effects occurred when the incubation medium was either a $\mathrm{Ca}^{2+}$-free HEPES-buffered saline containing $0.5 \mathrm{~mm}$ EGTA or a HEPES-buffered saline containing the calcium antagonist $\mathrm{Co}^{2+}$ (2.0 mM) (Stallcup, 1979).

Several phosphoproteins are known to undergo alterations in their electrophoretic mobilities upon phosphorylation (e.g., Jahn and Soling, 1983; Stadel et al., 1983; Binder et al., 1984). To test the possibility that NGF or dbcAMP might change the state of phosphorylation of synapsin I, cells were labeled with ${ }^{32} \mathrm{P}$ phosphate, treated with either agent and the synapsin I purified by immunoprecipitation. The autoradiogram in Figure 5 shows that the mobility shifts are evident in ${ }^{32} \mathrm{P}$-phosphate-labeled synapsin I. These results indicate that both the faster and the slower-migrating species, as well as the basal species of synapsin I, are phosphorylated proteins. NGF, but not dbcAMP, caused an increase in the phosphate content of synapsin I. The additional phosphate incorporated into synapsin I after NGF treatment was present exclusively in the $10 \mathrm{kDa}$ fragment generated by partial proteolysis with $S$. aureus V-8 protease (Fig. 6).

To characterize further the site(s) on synapsin I phosphorylated in response to NGF, phosphorylated synapsin I isolated from control, NGF-, and dbcAMP-treated PC12 cells was subjected to tryptic/chymotryptic proteolysis and fingerprint analysis. Digestion of synapsin I from both control cells (Fig. 7) and dbcAMP-treated cells (not shown) yielded 2 major phosphopeptides. No reproducible differences were noted between the phosphopeptide fingerprints of synapsin I from control and dbcAMP-treated cells. The phosphopeptide fingerprint of synapsin I from NGF-treated cells always contained a phosphopeptide in addition to these 2 , designated peptide $\mathrm{N}$ (for NGF- 


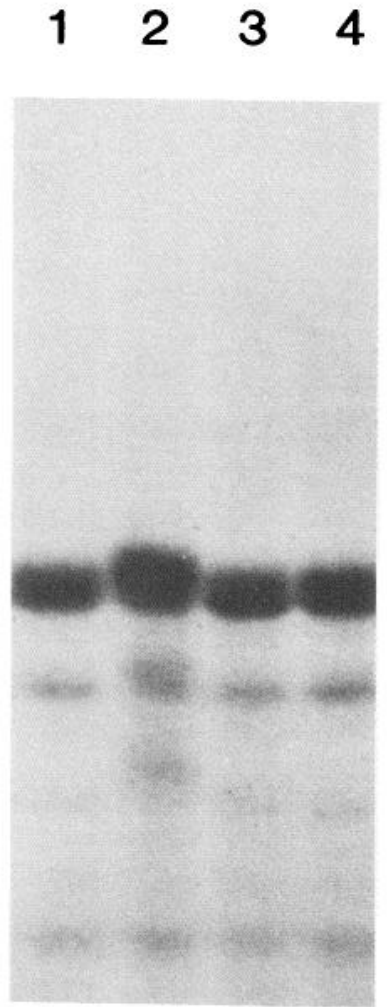

\section{\% Control 100134102100}

Figure 5. Effects of NGF and dbcAMP on the phosphate content of synapsin I. PC12 cells were labeled by incubation with ${ }^{32} \mathrm{P}$-phosphate for $1 \mathrm{hr}$. NGF or dbcAMP was then added and the incubation continued for another $30 \mathrm{~min}$. Cells were solubilized in 1\% SDS. From aliquots of SDS homogenates, containing equal amounts of TCA-precipitable radioactivity, ${ }^{32} \mathrm{P}$-phosphate-labeled synapsin I was purified by immunoprecipitation and SDS-PAGE. Lanes 1 and 4, control; lane 2, NGF; lane 3, dbcAMP. Values under each lane represent the radioactivity in synapsin I expressed as the percentage of control.

stimulated). In Figure 7, an additional peptide, $\mathrm{N}^{\prime}$, can also be seen. This peptide was not always present and was most likely an incomplete digestion product since its elution from the cellulose plate and further proteolysis yielded a phosphopeptide with the electrophoretic and chromatographic mobilities of peptide N. Phosphoserine was the only phosphoamino acid detected in peptide $\mathrm{N}$ (Fig. 8).

Synapsin I from brain is a physiological substrate for 3 protein kinases, namely, cyclic AMP-dependent protein kinase, calcium/calmodulin-dependent protein kinase I, and calcium/calmodulin-dependent protein kinase II. In addition, purified synapsin I can be phosphorylated by protein kinase C (A. C. Nairn, unpublished observations), although this latter phosphorylation appears not to be physiologically significant (Wang et al., 1985). Phosphopeptide fingerprint analysis of brain synapsin I phosphorylated by these different protein kinases demonstrated that they phosphorylate distinct parts of the molecule (Huttner et al., 1981). Phosphorylation with either cyclic AMP-dependent protein kinase or calcium/calmodulin-dependent protein kinase I yields a phosphopeptide, designated phosphopeptide 1, upon fingerprint analysis (A. C. Nairn, unpublished observations). Phosphorylation with either calcium/calmodulin-dependent protein kinase II (Huttner et al., 1981) or protein kinase C

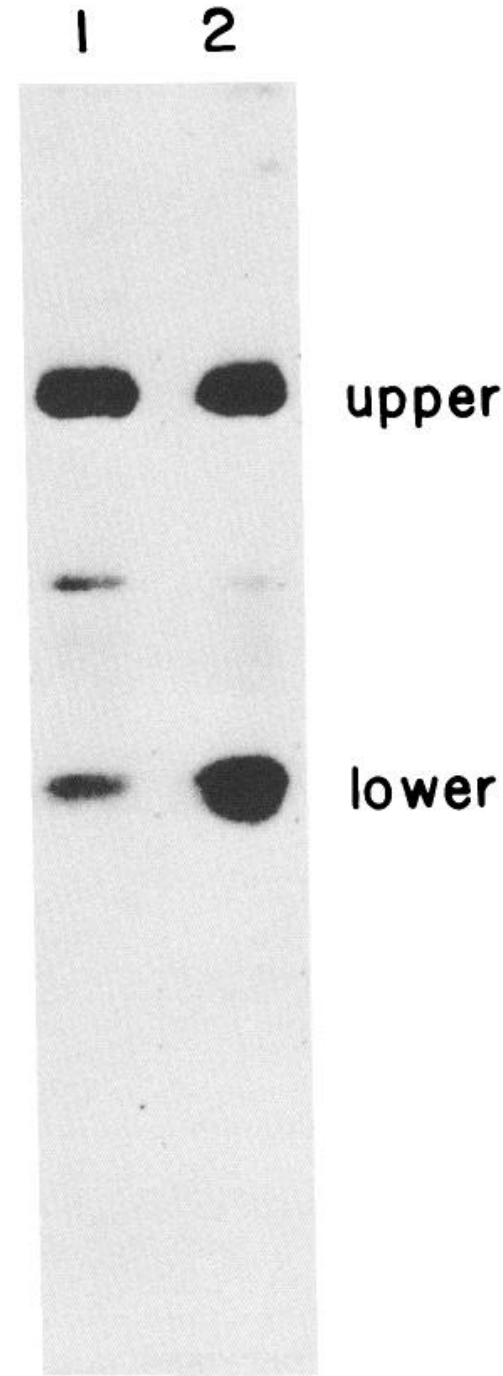

\section{$10097 \%$ control, upper $100285 \%$ control, lower}

Figure 6. Effect of NGF on phosphorylation of synapsin I as analyzed by partial proteolytic peptide mapping. ${ }^{32} \mathrm{P}$-phosphate-labeled synapsin I, prepared from PC12 cells treated in the absence (lane 1) or presence of NGF (lane 2) as described in the legend to Figure 5, was peptidemapped using $5 \mu \mathrm{g} S$. aureus protease by the method of Cleveland et al. (1977). The positions of the $35 \mathrm{kDa}$ (upper) and $10 \mathrm{kDa}$ (lower) phosphopeptides previously described for limited $S$. aureus proteolysis of synapsin I (Huttner and Greengard, 1979) are as indicated. Values under each line represent the radioactivity in each proteolytic phosphopeptide expressed as a percentage of control. The minor phosphopeptide intermediate between the upper and lower phosphopeptides is a $18 \mathrm{kDa}$ fragment derived from protein IIIa (Browning and Greengard, 1984), which migrates on SDS-PAGE very near to synapsin I and was variably present.

(unpublished observations) yields 4 phosphopeptides, designated peptides 2-5.

Phosphopeptide $\mathrm{N}$ from PC12 synapsin I did not correspond to any of the 5 known brain phosphopeptides. It migrated faster in the chromatographic dimension and more anodally during electrophoresis. Therefore, the NGF-stimulated phosphoryla- 


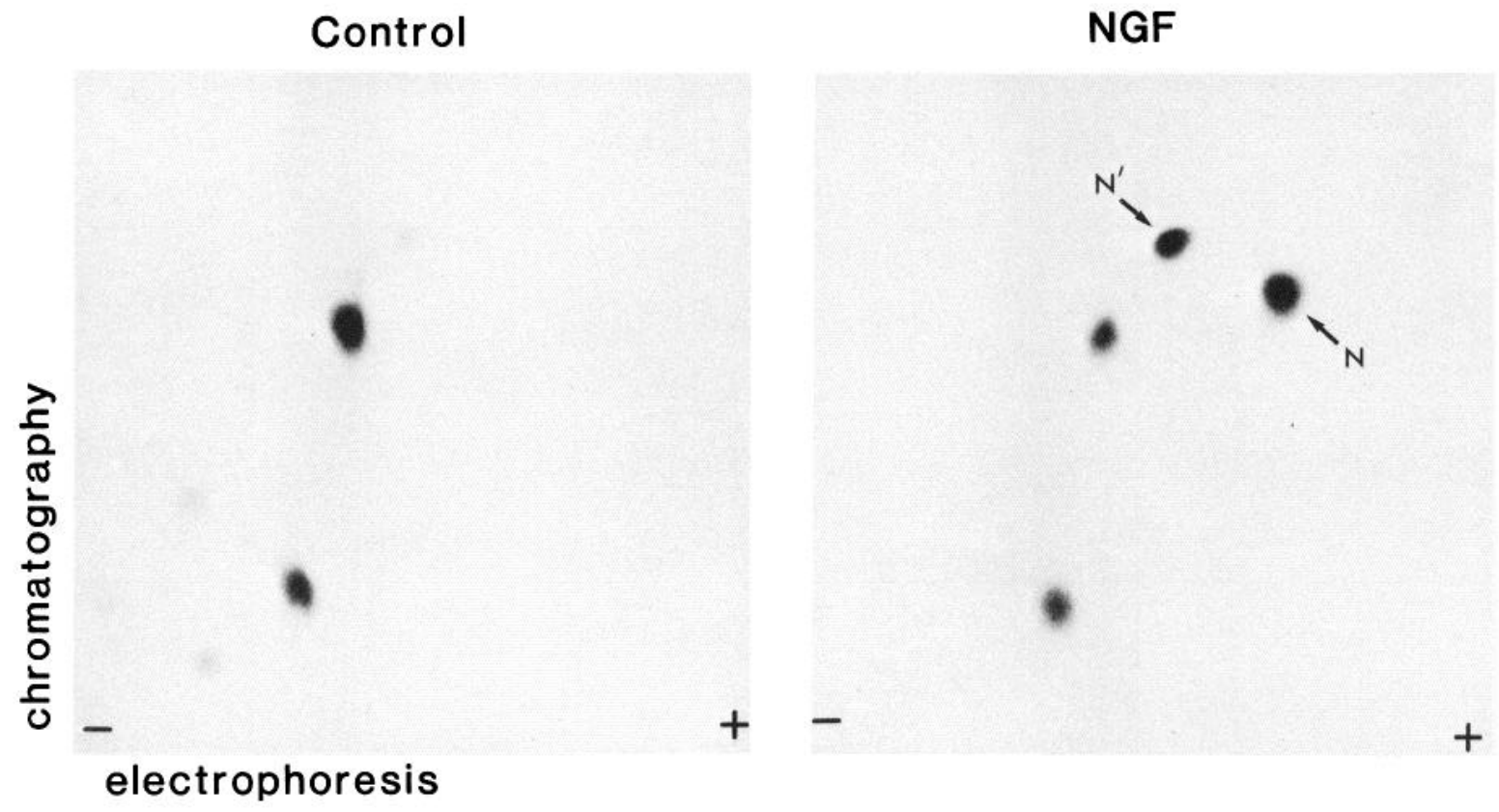

Figure 7. Effect of NGF on the phosphorylation of synapsin I as analyzed by limit proteolysis and phosphopeptide fingerprinting. ${ }^{32} \mathrm{P}$-phosphatelabeled synapsin I prepared from control and NGF-treated PC1 2 cells, as described in the legend to Figure 5, was subjected to tryptic/chymotryptic digestion and phosphopeptide fingerprinting. The NGF-stimulated phosphopeptides are labeled $\mathrm{N}$ and $\mathrm{N}^{\prime}$. As noted in the text, redigestion of peptide $\mathrm{N}^{\prime}$ yielded $\mathrm{N}$.

tion of peptide $\mathrm{N}$ must have been due either to a novel protein kinase or to a difference between PC12 synapsin I and brain synapsin I. To test the latter possibility, synapsin I was extracted and partially purified from PC12 cells, phosphorylated by the 4 individual protein kinases, and subjected to phosphopeptide fingerprinting. For each of the protein kinases tested, the tryptic/ chymotryptic phosphopeptide pattern obtained from PC12 synapsin I was nearly identical to that obtained from brain synapsin I. Figure 9 compares the phosphopeptide fingerprints of rat brain and PC12 synapsin I phosphorylated by cyclic AMP-dependent protein kinase and calcium/calmodulin-dependent protein ki-

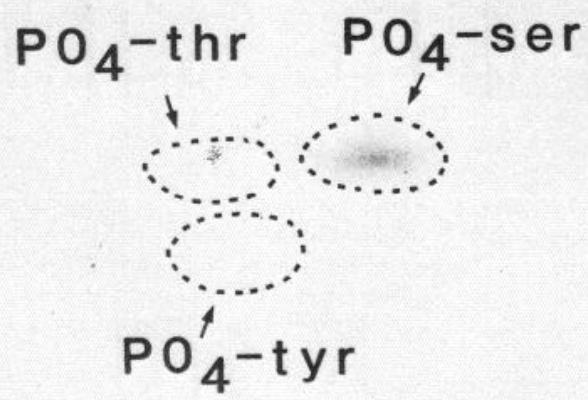

Figure 8. Phosphoamino acid analysis of peptide N. Positions of the phosphoamino acid standards are outlined. nase II. Neither of these kinases nor calcium/calmodulin-dependent protein kinase I nor protein kinase $\mathrm{C}$ yielded a phosphopeptide corresponding to peptide $\mathrm{N}$. These data indicate that the NGF-stimulated phosphorylation of synapsin I was not mediated by any of these kinases.

\section{Discussion}

NGF and dbcAMP treatment of intact PC12 cells induced rapid and opposite effects on the electrophoretic mobility of synapsin I in SDS-PAGE. These results indicate that the action of NGF is not mediated by increases in the intracellular cyclic AMP concentration. Forskolin, which increases intracellular cyclic AMP concentrations, did mimic the dbcAMP action on the electrophoretic mobilities of synapsin I and proteins IIIa and IIIb. NGF altered only the mobility of synapsin I and dbcAMP altered only the mobility of synapsin I and related proteins IIIa and IIIb.

Since NGF is necessary for the survival and maintenance of sympathetic neurons, and synapsin $I$ is present in all mature, functioning sympathetic neurons (DeCamilli et al., 1979, 1983a; Fried et al., 1982), the demonstration of a biochemical link between NGF and synapsin I is important. The association of synapsin I with small synaptic vesicles (DeCamilli et al., 1983b; Navone et al., 1984), and the control of its phosphorylation by neurotransmitters and neuromodulators (Nestler and Greengard, 1980; Dolphin and Greengard, 1981; Tsou and Greengard, 1982; Mobley and Greengard, 1985) strongly suggest a role for synapsin I in presynaptic processes regulating synaptic transmission (Nestler and Greengard, 1984). Recently, intracellular injection of synapsin I into the preterminal digit of the squid giant synapse has provided direct evidence for a role of synapsin I in the regulation of neurotransmitter release (Llinás et al., 1985). It will be of interest to determine whether the NGFinduced phosphorylation of synapsin I is important for its func- 
cAMP-dependent PK
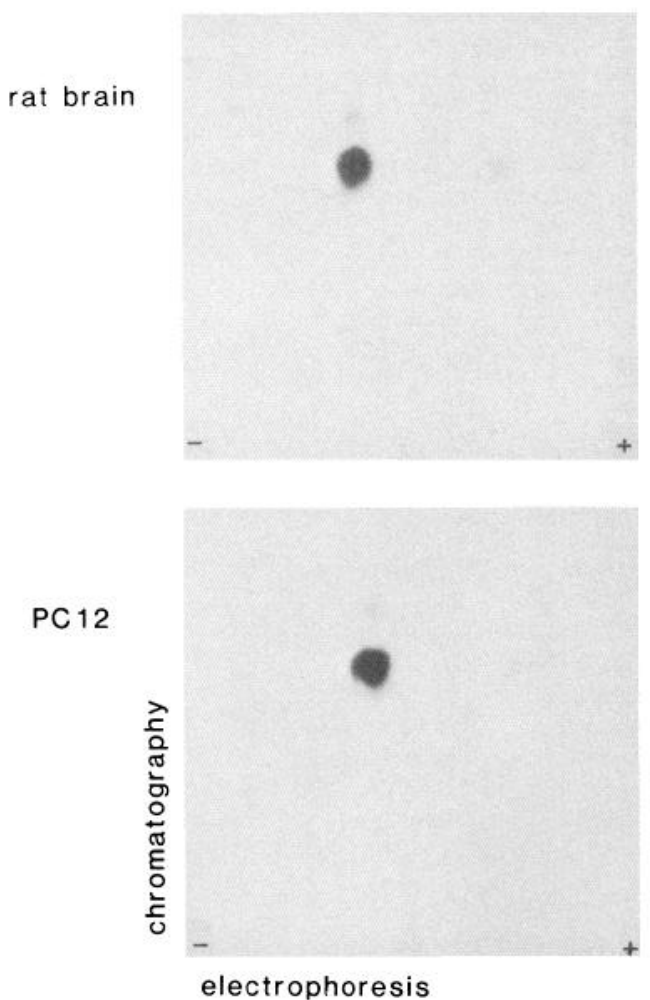

$\mathrm{Ca} / \mathrm{CaM}$-dependent PK II
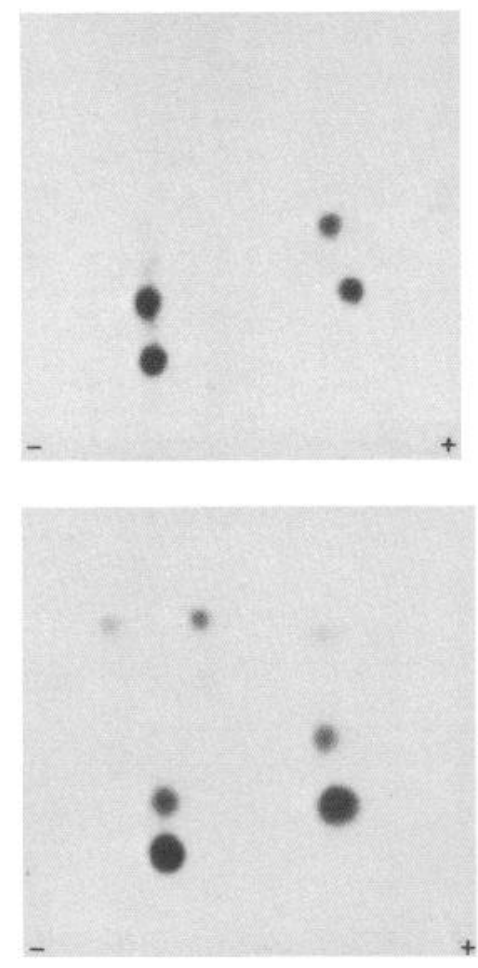

Figure 9. Comparison of the phosphopeptide fingerprints of rat brain and PC12 synapsin I phosphorylated by purified protein kinases. Synapsin I purified from rat brain or partially purified from PC12 cells was phosphorylated using purified catalytic subunit of the cAMP-dependent protein kinase or purified calcium/calmodulin-dependent protein kinase II. The phosphorylated synapsin I was purified from the reaction mixtures by immunoprecipitation followed by SDS-PAGE and then subjected to phosphopeptide fingerprint analysis. tioning. In addition, the specific phosphorylation of synapsin I induced by NGF provides an approach to the study of the molecular mechanism of action of NGF.

NGF has been shown to alter rapidly the state of phosphorylation of various proteins both in PC12 cells and in cultured sympathetic neurons (Halegoua and Patrick, 1980; Yu et al., 1980; End et al., 1983; Por and Huttner, 1984; Landreth and Reiser, 1985). Halegoua and Patrick (1980) observed NGFstimulated phosphorylation of several proteins in PC12 cells, including tyrosine hydroxylase (TH) and ribosomal protein S6. A detailed study of TH phosphorylation in PC12 cells has recently been presented (McTigue et al., 1985). Phosphorylation and activation of this enzyme was observed upon treating PC12 cells in situ with NGF, dbcAMP, cholera toxin, EGF, PMA, or elevated $\mathrm{K}^{+}$. The phosphopeptide fingerprint of $\mathrm{TH}$ from cells treated with NGF differed from the TH fingerprints from cells treated with any of the other agents. These results are not inconsistent with our own. Rowland et al. (1985) have detected a novel TH-kinase activity in extracts of $\mathrm{PC} 12$ cells that was stimulated by treating the intact cells with NGF for several minutes. The relationship between this TH-kinase and the kinase that phosphorylates synapsin $\mathrm{I}$ on peptide $\mathrm{N}$ remains to be determined.

As shown in the present study, PC12 synapsin I did serve as a substrate for all of the kinases known to phosphorylate brain synapsin I. However, none of those kinases phosphorylated the molecule on peptide $\mathrm{N}$. The simplest explanation for the NGF stimulation of PC12 synapsin I phosphorylation on peptide $\mathrm{N}$ is that NGF activates a novel synapsin I kinase with substrate specificity distinct from the known synapsin I kinases.

The mechanism by which cyclic AMP alters the electrophoretic mobility of PC12 synapsin I remains unexplained. An increase in synapsin I phosphorylation due to activation of cyclic
AMP-dependent protein kinase would be expected but apparently did not occur. This absence of effect is presumably due to distinct compartmentalization of enzyme and substrate intracellularly since PC12 synapsin I is a substrate for cyclic AMPdependent protein kinase (Fig. 9) and this enzyme is detectable in PC1 2 cell extracts (data not shown). If the increased mobility of synapsin I and proteins IIIa and IIIb associated with increased intracellular cyclic AMP is due to a dephosphorylation, the phosphate must be removed from a site that is not turning over rapidly and hence was not appreciably labeled during the incubation period. Alternatively, we cannot exclude that cyclic AMP leads indirectly to a different sort of chemical modification of these molecules. The similarity of the changes in mobility of synapsin I and proteins IIIa and IIIb suggests a coordinate regulation of these related molecules by cyclic AMP.

\section{References}

Binder, L.I., A. Frankfurter, H. Kim, A. Caceres, M. R. Payne, and L. I. Rebhun (1984) Heterogeneity of microtubule-associated protein 2 during rat brain development. Proc. Natl. Acad. Sci. USA 81: $5613-$ 5617.

Bradshaw, R. A. (1983) Nerve growth factor and related hormones. In Biochemical Actions of Hormones, G. Litwack, ed., pp. 91-114, Academic, New York.

Browning, M. D., and P. Greengard (1984) A family of synaptic vesicle-associated phosphoproteins: Synapsin Ia, synapsin Ib, protein IIIa, and protein IIIb. Soc. Neurosci. Abstr. 10: 196.

Bylund, D. B., and T.-S. Huang (1976) Decomposition of phosphoserine and phosphothreonine during acid hydrolysis. Anal. Biochem. 73: 477-485.

Cleveland, D. W., S. G. Fischer, M. W. Kirschner, and U. K. Laemmli (1977) Peptide mapping by limited proteolysis in sodium dodecyl sulfate and analysis by gel electrophoresis. J. Biol. Chem. 252: 11021106.

Connolly, J. L., L. A. Greene, K. R. Viscarello, and W. D. Riley (1979) Rapid, sequential changes in surface morphology of PC12 pheo- 
chromocytoma cells in response to nerve growth factor. J. Cell Biol. 82: $820-827$.

Curran, T., and J. I. Morgan (1985) Superinduction of c-fos by nerve growth factor in the presence of peripherally active benzodiazepines. Science 229: 1265-1268.

DeCamilli, P., T. Ueda, F. E. Bloom, E. Battenberg, and P. Greengard (1979) Widespread distribution of protein $I$ in the central and peripheral nervous systems. Proc. Natl. Acad. Sci. USA 76: 5977-5981.

DeCamilli, P., R. Cameron, and P. Greengard (1983a) Synapsin I (protein I), a nerve terminal-specific phosphoprotein. I. Its general distribution in synapses of the central and peripheral nervous system demonstrated by immunofluorescence in frozen and plastic sections. J. Cell Biol. 96: 1337-1354.

DeCamilli, P., S. M. Harris, Jr., W. B. Huttner, and P. Greengard (1983b) Synapsin I (protein I), a nerve terminal-specific phosphoprotein. II. Its specific association with synaptic vesicles demonstrated by immunocytochemistry in agarose-embedded synaptosomes. J. Cell Biol. 96: 1355-1373.

Dolphin, A. C., and P. Greengard (1981) Neurotransmitter- and neuromodulator-dependent alterations in phosphorylation of protein I in slices of rat facial nucleus. J. Neurosci. 1: 192-203.

End, D., N. Tolson, S. Hashimoto, and G. Guroff (1983) Nerve growth factor-induced decrease in the cell-free phosphorylation of a soluble protein in PC12 cells. J. Biol. Chem. 258: 6549-6533.

Fried, G., E. J. Nestler, P. DeCamilli, L. Stjarne, L. Olson, J. M. Lundberg, T. Hökfelt, C. C. Ouimet, and P. Greengard (1982) Cellular and subcellular localization of protein $I$ in the peripheral nervous system. Proc. Natl. Acad. Sci. USA 79: 2717-2721.

Greenberg, M. E., L. A. Greene, and E. B. Ziff (1985) Nerve growth factor and epidermal growth factor induce rapid transient changes in proto-oncogene transcription in PC12 cells. J. Biol. Chem. 260: 1410114110.

Greene, L. A., and E. M. Shooter (1980) Nerve growth factor: Biochemistry, synthesis and mechanism of action. Annu. Rev. Neurosci. 3: 353-402.

Greene, L. A., P. J. Seeley, A. Rukenstein, M. DiPiazzo, and A. Howard (1984) Rapid activation of tyrosine hydroxylase in response to nerve growth factor. J. Neurochem. 42: 1728-1734.

Halegoua, S., and J. Patrick (1980) Nerve growth factor mediates phosphorylation of specific proteins. Cell 22: 571-581.

Horii, Z.-I., and S. Varon (1977) Nerve growth factor action on membrane permeation to exogenous substrates in dorsal root ganglionic dissociates from the chick embryo. Brain Res. 124: 121-133.

Hunter, T., and B. M. Sefton (1980) The transforming gene product of Rous sarcoma virus phosphorylates tyrosine. Proc. Natl. Acad. Sci. USA 77: 1311-1315.

Huttner, W. B., and P. Greengard (1979) Multiple phosphorylation sites in protein I and their differential regulation by cyclic AMP and calcium. Proc. Natl. Acad. Sci. USA 76: 5402-5406.

Huttner, W. B., L. J. DeGennaro, and P. Greengard (1981) Differential phosphorylation of multiple sites in purified protein I by cyclic AMPdependent and calcium-dependent protein kinases. J. Biol. Chem. 256: 1482-1488.

Huttner, W. B., W. Schiebler, P. Greengard, and P. De Camilli (1983) Synapsin I (protein I), a nerve terminal-specific phosphoprotein. III. Its association with synaptic vesicles studied in a highly purified synaptic vesicle preparation. J. Cell Biol. 96: 1374-1388.

Jahn, R., and H. D. Soling (1983) Phosphorylation of the ribosomal protein $S 6$ in response to secretagogues in the guinea pig exocrine pancreas, parotid and lacrimal gland. FEBS Lett. 153: 71-76.

Landreth, G. E., and G. D. Reiser (1985) Nerve growth factor- and epidermal growth factor-stimulated phosphorylation of a PC12 cytoskeletally associated protein in situ. J. Cell Biol. 100:677-683.

Levi-Montalcini, R., and P.U. Angeletti (1968) Nerve growth factor. Physiol. Rev. 48: 534-569.
Llinás, R. T. L. McGuinness, C. S. Leonard, M. Sugimori, and P. Greengard (1985) Intraterminal injection of synapsin I or calcium/ calmodulin-dependent protein kinase II alters neurotransmitter release at the squid giant synapse. Proc. Natl. Acad. Sci. USA 82: 30353039.

McGuire, J. C., and L. A. Greene (1979) Rapid stimulation by nerve growth factor of amino acid uptake by clonal PC- 12 pheochromocytoma cells. J. Biol. Chem. 254: 3362-3367.

McTigue, M., J. Cremins, and S. Halegoua (1985) Nerve growth factor and other agents mediate phosphorylation and activation of tyrosine hydroxylase. J. Biol. Chem. 260: 9047-9056.

Mobley, P., and P. Greengard (1985) Evidence for widespread effects of noradrenaline on axon terminals in the rat frontal cortex. Proc. Natl. Acad. Sci. USA 82: 945-947.

Navone, F., P. Greengard, and P. DeCamilli (1984) Synapsin I in nerve terminals: Selective association with small synaptic vesicles. Science 226: 1209-1211.

Nestler, E. J., and P. Greengard (1980) Dopamine and depolarizing agents regulate the state of phosphorylation of protein I in the mammalian superior cervical sympathetic ganglion. Proc. Natl. Acad. Sci. USA 77: 7479-7483.

Nestler, E. J., and P. Greengard (1984) Protein Phosphorylation in the Nervous System, Wiley, New York.

Por, S. B., and W. B. Huttner (1984) A $\mathrm{M}_{\mathrm{r}} 70,000$ phosphoprotein of sympathetic neurons regulated by nerve growth factor and by depolarization. J. Biol. Chem. 259: 6526-6533.

Rabe, C. S., J. Schneider, and R. McGee, Jr. (1982) Enhancement of depolarization-dependent neurosecretion from PC12 cells by forskolin-induced elevation of cyclic AMP. J. Cyclic Nucleotide Res. 8: 371-384.

Romano, C., R. A. Nichols, P. Greengard, and L. A. Greene (1987) Synapsin I in PC1 2 cells. I. Characterization of the phosphoprotein and effect of chronic NGF treatment. J. Neurosci. 7: 1294-1299.

Rowland, E. A., T. H. Muller, M. Goldstein, and L. A. Green (1985) Cell free detection of an NGF-activated kinase activity in $\mathrm{PC1} 2$ cells. Soc. Neurosci. Abstr. 11: 659.

Seamon, K. B., W. Padgett, and J. W. Daly (1981) Forskolin: Unique diterpene activator of adenylate cyclase in membranes and in intact cells. Proc. Natl. Acad. Sci. USA 78: 3363-3367.

Seeley, P. J., and P. Greengard (1983) Short-latency local actions of nerve growth factor at the growth cone. Proc. Natl. Acad. Sci. USA 80: 2789-2793.

Stadel, J. M., P. Nambi, R. G. L. Shorr, D. F. Sawyer, M. G. Caron, and R. J. Letkowitz (1983) Catecholamine-induced densensitization of turkey erythrocyte adenylate is associated with phosphorylation of the $\beta$-adrenergic receptor. Proc. Natl. Acad. Sci. USA 80: 3173-3177.

Stallcup, W. B. (1979) Sodium and calcium fluxes in a clonal nerve cell line. J. Physiol. (Lond.) 286: 525-540.

Thoenen, H., and Y.-A. Barde (1980) Physiology of nerve growth factor. Physiol. Rev. 60: 1284-1335.

Tsou, K., and P. Greengard (1982) Regulation of phosphorylation of proteins $\mathrm{I}, \mathrm{III}_{\mathrm{a}}$, and $\mathrm{III}_{\mathrm{b}}$ in rat neurohypophysis in vitro by electrical stimulation and by neuroactive agents. Proc. Natl. Acad. Sci. USA 79: $6075-6079$.

Ueda, T., and P. Greengard (1977) Adenosine 3':5'-monophosphateregulated phosphoprotein system of neuronal membranes. I. Solubilization, purification, and some properties of an endogenous phosphoprotein. J. Biol. Chem. 252: 5155-5163.

Wang, J. K. T., S. I. Walaas, and P. Greengard (1985) Soc. Neurosci. Abstr. 11:846.

Yu, M. Y. W., N. W. Tolson, and G. Guroff (1980) Increased phosphorylation of specific nuclear proteins in superior cervical ganglia and PC12 cells in response to nerve growth factor. J. Biol. Chem. 255: 10481-10492. 